\title{
Carabid functional diversity is enhanced by conventional flowering fields, organic winter cereals and edge habitats
}

\author{
Christoph Gayer ${ }^{\mathrm{a}, *}$, Gábor L. Lövei ${ }^{\mathrm{b}}$, Tibor Magura ${ }^{\mathrm{c}}$, Martin Dieterich ${ }^{\mathrm{d}}$, Péter Batáry e, f \\ a Institute of Landscape and Environment (ILU), University of Applied Science Nürtingen-Geislingen, 72622, Nürtingen, Germany \\ ${ }^{\mathrm{b}}$ Department of Agroecology, Flakkebjerg Research Center, Aarhus University, 4200, Slagelse, Denmark \\ ${ }^{c}$ Department of Ecology, University of Debrecen, 4032, Debrecen, Hungary \\ ${ }^{\mathrm{d}}$ Landscape Ecology and Vegetation Science, University of Hohenheim, 70599, Stuttgart, Germany \\ e Agroecology, University of Göttingen, 37077, Göttingen, Germany \\ ${ }^{\mathrm{f}}$ Lendület Landscape and Conservation Ecology, Institute of Ecology and Botany, MTA Centre for Ecological Research, Vácrátót, Hungary
}

\section{ART ICLE INFO}

\section{Keywords:}

Agri-environmental schemes

Arable fields

Field margins

Herbivores

Landscape structure

Traits

\begin{abstract}
A B S T R A C T
The continued decline in farmland biodiversity in Europe despite substantial funding for agri-environment schemes (AES) has prompted calls for more effective biodiversity conservation measures. The current AES regime allows for both holistic measures, such as organic farming, that broadly target the agricultural environment and biodiversity-specific measures, such as flowering fields, but little is known of their relative efficacies. To address this gap, we studied carabids in 48 arable fields that presented four crop types under different management practices along a gradient of landscape complexity: (a) conventionally managed crop (winter wheat), (b) biodiversity-specific AES under conventional management (sown flowering field), (c) organically managed mono-crop (winter spelt) and (d) organically managed lentil-mixedcrop (lentil intercropped with cereal or camelina). For these crop-use types, we compared functional diversity of carabid assemblages at the edge and center of the fields. Using pitfall traps, we collected more than 55,000 carabids of 95 species over two years. We characterized diversity using community weighted means and functional divergence of three ecological traits - body size, feeding type, and flight ability. Conventional flowering fields and organic winter spelt, but not organic spring sown lentil-mixed-crop, increased the proportion of plant feeding carabids; moreover, trait characteristics and their divergences were most affected by field edges, with smaller, less carnivorous and more flight-enabled carabid assemblages found there than in the center. Divergence of body size and feeding type but not of flight ability was larger at the field edges than centres. Surrounding landscape complexity did not affect carabid traits. We conclude that future AES policy should avoid strict decisions between biodiversity specific- and holistic measures. Instead, priority should be given to a diversity of different measures, targeting the enhancement of edge habitats as well as productive and non-productive measures.
\end{abstract}

\section{Introduction}

To halt the loss of farmland biodiversity in the European Union, agri-environment schemes (AES) provide financial support to farmers who follow environmentally friendly practices (Henle et al., 2008). Although the EU allocates a significant portion of its budget to AES ( $€$ 2.5 billion $\mathrm{y}^{-1}$ ), biodiversity continues to decline (Flohre et al., 2011; Westerink et al., 2017). This has led to repeated calls for more effective biodiversity conservation in agri-environment schemes (Kleijn and Sutherland, 2003; Kleijn et al., 2011; Batáry et al., 2015). How to cre- ate such schemes requires insight into the impact of specific agri-environment measures (AEM) on farmland biodiversity.

Recently, different types of AES have been implemented, targeting either the establishment of non-productive areas (e.g. sown flowering field schemes) or the reduction of farming intensity in productive areas (e.g. organic farming) (Mader et al., 2017). Sown flowering fields, which primarily target biodiversity conservation, have become more common within arable farming regions in Europe (e.g. England, Germany and Switzerland), (Haaland et al., 2011; Batáry et al., 2015; Boetzl et al., 2018). Organic farming, which is supported under the AES regime in Europe, follows a more holistic approach, focusing on

\footnotetext{
* Corresponding author at: Hechingerstr. 12, 72622, Nürtingen, Germany.

Email address: christoph.gayer@hfwu.de (C. Gayer)
} 
ecologically responsible low input agriculture (IFOAM, 2005). Hence, biodiversity conservation is just one of several objectives of organic farming. Compared to organic farming systems, a history of shorter crop rotations as well as long term effects of pesticide and mineral fertilizer applications in conventional farming systems (Bruggen et al., 2016) may lessen or even neutralize any beneficial effects on biodiversity from sown flowering fields. The question remains could AES that are more targeted toward biodiversity conservation deliver greater results for biodiversity than measures which focus broadly on the overall agricultural environment?

Despite high subsidies, direct comparisons of the biodiversity conservation effects of different AES measures and organic farming are rare. Most studies focus on activity density, species richness or community composition (Caro et al., 2016; Labruyere et al., 2016b; Mader et al., 2017). Meanwhile, the central question of how different AEMs affect functional diversity based on species traits has received scant attention (Rusch et al., 2013; but see Boetzl et al., 2018). Focusing on functional, rather than taxonomic, diversity can provide more insight into the mechanisms by which changes in land use impact biodiversity (Rusch et al., 2013; Woodcock et al., 2014; Gallé et al., 2018a). Functional diversity also provides a more sensitive determinant of environmental changes and ecosystem processes (de Bello et al., 2010; Woodcock et al., 2014). Hence, it is essential to understand the effects of different AEMs and farming types on functional diversity in order to increase the effectiveness of future AES regimes.

As study organisms, we chose ground beetles (Coleoptera: Carabidae), because they are highly sensitive towards habitat change and agricultural practices, such as tillage or pesticide use (Lövei and Sunderland, 1996), and they can respond to the degree of extensiveness of farming practice (Caro et al., 2016). Establishing flowering fields or organic farming can alter carabid assemblages and their trait composition, but effects vary depending on which traits and AES measures are considered. For instance, Mader et al. (2017) observed no significant differences in body size distribution of carabids between organically farmed cereals and sown flowering fields, but Boetzl et al. (2018) found significant effects of flowering fields on body size as well as feeding type distribution of carabid assemblages. Flight ability also responds to different farming practices (e.g. Ribera et al., 2001; Caprio et al., 2015).

Irrespective of local habitat management, carabids within arable fields may also be affected by edge effects from bordering non-cultivated habitats, such as grassy field margins, that provide shelter, overwintering habitat and other resources (Schirmel et al., 2016; Gallé et al., 2018b). Due to spillover effects, grassy field margins can shape trait characteristics of arthropod assemblages in arable fields, as they provide different ecological niches by a contrasting disturbance regime, microclimate, vegetation structure and -composition compared to arable fields (Rouabah et al., 2015; Labruyere et al., 2016b; Schirmel et al., 2016). Consequently, functional diversity may differ considerably between the edges and the center of arable fields. The complexity of the surrounding landscape can be a further important factor in shaping both carabid assemblages and functional composition (e.g. Purtauf et al., 2005a). For example, simple landscapes support smaller carabids than do complex ones (Gallé et al., 2018b), and carnivorous species show a stronger response to landscape structure than do herbivorous ones (Woodcock et al., 2010).

Here we aimed to study functional diversity of carabid assemblages in response to three agri-environmental measures: a biodiversity specific AES under conventional management (sown flowering fields) and mono-, as well as a mixed-crop under organic management. Conventionally managed winter wheat fields served as control. For these four crop-use types, we assessed the distribution and divergence of three ecological traits of the resident carabid assemblages: body size, feeding type, and flight ability. Specifically, we posed the following questions:
(1) whether functional diversity of carabid assemblages differs between the four crop-use types, (2) whether there are differences between the edge and the centre of arable fields, irrespective of crop-use type, and (3) how the functional diversity of carabid assemblages is shaped by the complexity of the surrounding landscape.

\section{Materials and methods}

\subsection{Study area and study design}

We studied carabid assemblages under four crop-use types: (a) conventionally managed winter wheat (Triticum aestivum L.), (b) conventionally managed sown flowering fields, (c) organically managed winter spelt (Triticum aestivum subsp. spelta L) and (d) organically managed lentil with supporting crop (Lens culinaris Medic. intercropped with

cereal or camelina, Camelina sativa L.). Each crop-use type was sampled in 12 sites over two years (2016 and 2017) with a sample size of six in each of the two study years $\left(n_{\text {total }}=12\right)$. In each study year we chose different study fields for each crop-use type due to crop rotation.

We selected 48 study fields ( 4 crop-use types $\times 6$ sites $\times 2$ years) in the Central Swabian Jurassic mountains in south-western Germany (Appendix A1 in supplementary material). All sites are located within the UNESCO Biosphere Reserve Swabian Alb. The Swabian Alb is a low mountainous area situated in the center of the state of Baden-Württemberg, Germany. Due to a history of small-scale land use, the region is characterized by small field sizes. Terrain elevation of the Swabian Alb ranges between 460 and $860 \mathrm{~m}$ a.s.l. (Egorov et al., 2017). Soils were shallow and poor luvisols or cambisols with a bedrock of White Jurassic limestone (IUSS WG WRB, 2015).

We sampled carabids along two transects per study field ( $n=96$ transects). One transect was placed at the field edge within the first crop row, adjacent to a grassy margin (permanent meadow strip) as a standardized neighboring habitat, mostly accompanied by field paths. When no bordering grassy field margin was available, we chose a fertilized grassland as bordering habitat (4 cases). The central transect was placed orthogonally to the edge transect within the study field forming a "T" shape (Fig. S1); this was necessary due to the small width of some study fields (minimum width $24 \mathrm{~m}$ ). The minimum distance between the edge and the center transects was standardized to $12 \mathrm{~m}$ in 2016 and $15 \mathrm{~m}$ in 2017 for all study fields. This minimum distance (smallest possible distance between edge and center) was always determined considering the dimensions of the smallest study field. The mean field size was 2.2 ha (SE: 0.2 ha) with similar field sizes between crop-use types (winter wheat: $2.3 \pm 0.5$ ha; flowering field: $2.3 \pm 0.6$ ha; winter spelt: $2.0 \pm 0.3$ ha; lentil-mixed-crop: $2.1 \pm 0.6 \mathrm{ha}$ ) and varied between study sites from $1.4 \pm 0.3$ ha to $3.4 \pm 1.5$ ha.

To study the impact of landscape complexity, crop-use type and transect position (field edge vs. center) on functional diversity, we applied a fully cross-nested design, spatially nesting crop-use types per study site (Fig. S1). Each study site spatially blocked the four crop-use types. We selected twelve study sites (six per study year) in order to standardize the effects of landscape context and local site conditions (soil and climate) across crop-use types. The mean minimum distance between study fields in the same site was much smaller $(0.63 \pm 0.1 \mathrm{~km})$ than the minimum distance between study fields of different study sites $(4.7 \pm 0.9 \mathrm{~km})$. Within each study site, the two conventional crop-use types (winter wheat, flowering field) as well as the two organic crop-use types (winter spelt, lentil-mixed-crop) were farmed by the same farmer (conventional or organic). The pairwise nesting of study fields within each study site minimized the potential impact of variable farming practices by different farmers. Besides this double nesting, crop-use types were also crossed over management type (conventional vs. organic), as each management type always had one flowering (flowering field, lentil-mixed-crop) and one cereal (win- 
ter wheat, winter spelt) crop associated with it. The result was a cross-nested study design.

\subsection{Farming characteristics of study fields}

Data on the farming practice used on each study field were collected via personal interviews with the farmers $(n=24)$ using a standardized questionnaire. Annual nitrogen supply $\left(\mathrm{kgNha}^{-1}\right)$ was calculated by summing the amount of applied mineral and/or organic fertilizers. While farmers gave precise information about the amount of mineral fertilizers used, information about organic fertilizer was less accurate and therefore recorded by type (liquid manure or dung) and quantity ( $\mathrm{m}^{3}$ of liquid manure, $\mathrm{kg}$ of dung). To calculate the amount of applied nitrogen by organic substrates, we multiplied the quantity of the used substrate with standard values for nitrogen content: $4.0 \mathrm{~kg} \mathrm{~N}\left(\mathrm{~m}^{3}\right)^{-1}$ for liquid manure and $5 \mathrm{~kg} \mathrm{~N} \mathrm{t}^{-1}$ for dung (Fritsch, 2012). We characterized pesticide use by the number of applications of herbicide, fungicide or insecticide.

Flowering fields were annual set-asides sown with a standard seed mixture of 15-18 flowering plant species, predominantly non-native, but nonetheless traditionally cultivated in German horti- or agriculture (see Table S1 for a species list). Nine flowering fields were sown with seeding mixture M2 and three fields were sown with the mixture M1 (Table S1). AES regulations (MLR, 2016) do not allow management measures on flowering fields (no pesticide, no fertilizer, no tillage after sowing) for one year after their establishment.

The two organic crops were subsidized through standard AES support for organic farming. In contrast to conventional flowering fields, organic crops are not a specific AES type within the AES regime of the study area (Baden-Württemberg). The lentil crop was a flowering legume sown with a row spacing of approximately $13.5-15 \mathrm{~cm}$ (Gruber et al., 2012). It was sparsely intercropped (same row spacing) with camelina (three sites), barley (Hordeum vulgare; three sites) or oats (Avena sativa; six sites) in order to stabilize the lentil plants (Table S2, Fig. S2, for details about lentil mixed-cropping systems see Wang et al., 2012).

The four crop-use types differed in sowing time (autumn vs. spring sown crop), crop type (cereal vs. flowering plant) and management type (conventional vs. organic farming) (Table 1, Table S2). Cereal crops (winter wheat and winter spelt) were always sown in the autumn of the preceding year, while flowering crops (flowering field and lentil-mixed-crop) were sown in the spring. Herbicides, fungicides, insecticides and mineral fertilizers were applied only to winter wheat; mechanical weed control was only used in winter spelt. Compared to the conventional crop-use types, organic crop-use types had a more diverse crop rotation, more perennial crops (mainly clover-mixtures), and more plow-free soil tillage before sowing (Table 1, Table S2). Organic farming practices followed the European standards (The Council of the European Union, 2005), and all organic farmers were certified by the Bioland Association, with the exception of one certified by the Demeter Association. Yields as well as subsidies under AES differed between the crop-use types (Table 1).

\subsection{Landscape analysis}

To take into account potential landscape effects, we analyzed landscape complexity within a radius of $500 \mathrm{~m}$ around the midpoint of each study transect $(n=96)$. Arable land was the most abundant land cover type, with $56.7 \pm 1.8 \%$ of total cover (mean \pm SEM) showing a distinct gradient between study fields ranging from $15.1 \%$ to $83.0 \%$ of arable land cover. Arable land cover was independent of crop-use types $\left(\chi^{2}=5.4, \mathrm{df}=3, \mathrm{p}=0.15\right)$ or transect position $\left(\chi^{2}<0.01\right.$, $\mathrm{df}=1, \mathrm{p}=0.99$ ). Arable land cover was significantly negatively correlated with land use diversity (Shannon index; $\mathrm{r}_{94}=-0.83, \mathrm{p}<0.001$ ) and forest cover $\left(r_{94}=-0.68, p<0.001\right)$. This allowed us to use arable land cover as a simple predictor of landscape complexity. The Shannon index was calculated from the percentage cover of arable land, intensively managed grassland (e.g. fertile meadow), extensive grassland (e.g. calcareous grassland), copses (hedges, shrubs, single trees), forest, wetland (including water bodies) and urban elements. Landscape data were obtained from the project "Flächendeckende Biotop und Nutzungstypenkartierung im Biosphärengebiet Schwäbische Alb mittels Fernerkundungsdaten als Basis für ein Landschaftsmonitoring”, which provided an area-wide classification of habitat complexes of the Biosphere Reserve Swabian Alb, based on multisensoral remote sensing and environmental geodatasets (for details see Schlager et al., 2013). Landscape analysis was conducted using the Geographical Information System ArcGIS 10.2.2 (1999-2014 ESRI Inc.).

\subsection{Carabid and plant survey}

We sampled carabids by pitfall traps consisting of a polyvinychlorid (PVC) tube (diameter $7.2 \mathrm{~cm}$, height $10 \mathrm{~cm}$ ), into which a fitting $200 \mathrm{ml}$ polyethylene beaker was inserted and filled with approx. $100 \mathrm{ml}$ of a $30 \%$ ethylene glycol solution. A drop of non-scented detergent was added to reduce surface tension. To prevent vertebrate bycatch, a wire netting ( $20 \mathrm{~mm}$ mesh size) was installed approx. $3 \mathrm{~cm}$ beneath the opening. To prevent flooding, we placed a coated pressboard roof (approx. $15 \mathrm{~cm} \times 15 \mathrm{~cm}$ ) supported by a pair of $10 \mathrm{~cm}$ long iron nails. In each study field, we placed five traps at the edge and another five in the center, yielding 10 traps per study field, for a total of 240 traps per year. Distance between traps within each transect was stan-

\section{Table 1}

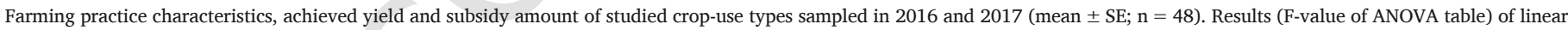
mixed-effects models are given to test for significant differences between crop-use types. Bold values indicate significant effect at $\mathrm{P}=0.05$.

\begin{tabular}{|c|c|c|c|c|c|c|c|c|c|}
\hline & & & $\begin{array}{l}\text { Sowing date } \\
\text { (calendar week) }\end{array}$ & $\begin{array}{l}\text { Crops in } \\
\text { rotation } \\
\text { (number) }\end{array}$ & $\begin{array}{l}\text { Fertilizer ( } k g \\
\left.N h a^{-1}\right)\end{array}$ & $\begin{array}{l}\text { Pesticide } \\
\text { application } \\
\text { (number) }\end{array}$ & $\begin{array}{l}\text { Mechanical } \\
\text { weeding } \\
\text { (number) }\end{array}$ & $\begin{array}{l}\text { Yield }(d t \\
\left.h a^{-1}\right)\end{array}$ & $\begin{array}{l}\text { Subsidy by } \\
\operatorname{AES}^{c}(\epsilon \\
\left.h a^{-1}\right)\end{array}$ \\
\hline \multirow[t]{2}{*}{ Conventional } & $\begin{array}{l}\text { Winter Wheat } \\
(\mathrm{n}=12)\end{array}$ & & $\begin{array}{l}40.2 \pm 0.4 \text { (early } \\
\text { October) }\end{array}$ & $3.9 \pm 0.2$ & $184.6 \pm 11.5$ & $2.3 \pm 0.4$ & $0.1 \pm 0.1$ & $68.8 \pm 3.6$ & none \\
\hline & $\begin{array}{l}\text { Flowering Field } \\
(\mathrm{n}=12)\end{array}$ & & $\begin{array}{l}18.2 \pm 0.3 \text { (early } \\
\text { May) }\end{array}$ & $3.9 \pm 0.2$ & $1.9 \pm 1.9$ & none & none & none & 710 \\
\hline \multirow[t]{2}{*}{ Organic } & $\begin{array}{l}\text { Winter Spelt } \\
(\mathrm{n}=12)\end{array}$ & & $\begin{array}{l}40.7 \pm 0.3 \text { (early } \\
\text { October) }\end{array}$ & $5.8 \pm 0.2$ & $71.2 \pm 21.4$ & none & $1.7 \pm 0.3$ & $29.9 \pm 1.7$ & 230 \\
\hline & $\begin{array}{l}\text { Lentil-mixed- } \\
\text { crop }(\mathrm{n}=12)\end{array}$ & & $\begin{array}{l}14.7 \pm 0.5(\mathrm{mid} \\
\text { of April) }\end{array}$ & $5.9 \pm 0.2$ & $4.9 \pm 3.4$ & none & none & $9.8 \pm 2.2$ & 230 \\
\hline \multirow[t]{2}{*}{ Model $^{\mathrm{a}}$} & $\mathrm{F}$ - value & Year & 0.8 & 23.8 & 0.1 & 0 & 0.1 & 0.2 & \\
\hline & & Crop & 1403.9 & 12.6 & 47.6 & 38 & 15.3 & 201.8 & \\
\hline
\end{tabular}

\footnotetext{
a All models were fitted with normal distribution.

b Only weeding between sowing and harvest counted.

c Fixed amount according to the agri-environmental scheme (AES) of the federal state Baden-Württemberg named FAKT (MLR, 2016).
} 
dardized to $10 \mathrm{~m}$ to minimize spatial autocorrelation. During sampling collection, trap contents were pooled within each transect. A sampling round lasted for 10 consecutive days. Between each sampling round, traps were kept closed for 10 days before the next sampling round started.

In the first study year, we conducted carabid trapping in three sampling rounds between 15 June and 3 August 2016, while in the second year, we used two sampling rounds between 15 June and 16 July 2017. In both years, we finished trapping immediately before crops were harvested or plowed. The overall sampling represented 12,000 trap days (240 traps $\times 50$ trapping days). All trapped carabids were preserved in $70 \%$ ethanol and later further identified to species level.

As vegetation structure and composition can strongly influence habitat conditions for carabids (Rouabah et al., 2015), we surveyed plant cover and species richness in order to examine differences between crop-use types. For details see the supplementary material (Appendix A2, Table S3).

During the sampling period, mean temperature and rainfall was $14.7^{\circ} \mathrm{C}$ with $195.9 \mathrm{~mm}$ rain in June and $17.0^{\circ} \mathrm{C}$ with $83.7 \mathrm{~mm}$ rain in July 2016. In 2017 , the means were $17.2^{\circ} \mathrm{C}$ and $96.9 \mathrm{~mm}$ in June and $16.5^{\circ} \mathrm{C}$ and $199.9 \mathrm{~mm}$ in July (dates from nearest meteorological station Münsingen-Apfelstetten, URL: https://cdc.dwd.de/, accessed 15.08.2015). For further analysis, we pooled data of all sampling occasions per transect per year.

\subsection{Carabid trait analysis}

To assess the functional diversity of carabids, we collected three functional trait values - body size, feeding type and flight ability for each species according to the literature (Table S4.). Body size was calculated as the geometric mean of minimum and maximum values in Homburg et al. (2014), followed by standardization to a range between 0 and 1 to decrease the effect of high values from large species (Gallé et al., 2018a). Feeding type was classified as herbivorous (including spermophagous), omnivorous or carnivorous based on the literature (Larochelle, 1990; Ribera et al., 2001; Purtauf et al., 2005a). Flight ability was categorized using wing morphology as fully winged, dimorphic or short winged/wingless using data from Hurka (1996).

We used community weighted means (CWM) of trait values to determine if specific trait characteristics of carabid assemblages were shaped by landscape complexity, crop-use type or transect position (Lavorel et al., 2008; Ricotta and Moretti, 2011). Further, we calculated functional divergence (FDvar) as a measure of functional trait distribution within carabid assemblages. FDvar values are higher when the abundance is higher towards either one or both margins of the trait distribution, and lower when abundance is concentrated towards the average trait value (Pla et al., 2012). We calculated FDvar indices according to Leps et al. (2006) and used the R package 'FD' to calculate CWM values (Laliberté et al., 2014).

\subsection{Statistical analysis}

We used linear mixed-effects models to statistically test for differences in farming practices between crop-use types and study years using the 'lme4' package (Bates et al., 2015) in the R program environment (R Development Core Team, 2017). To take into account the cross-nested design, we included the factors 'site', 'farmer' and 'crop type'(cereal vs. flowering crop) as nested random effects and 'crop-use type' and 'year' as fixed effects in the models by using the following R-syntax:

"Imer(y Crop-use type + Year + (1|Site/Farmer $)+(1 \mid$ Site/Crop type)".

We performed model diagnostics to test for normal distribution of model residuals, by investigating normal quantile-quantile plots and plotting model residuals against fitted values to visualize error distribution and check for heteroscedasticity. We applied the same approach to test for differences in vegetation characteristics between years, crop-use types and transects.

We used the above R-syntax for testing differences in arable land cover over a $500 \mathrm{~m}$ radius around study fields with 'crop-use type' and 'transect' (edge and center) as single and interacting fixed effects in the model. In order to assess significant differences between crop-use types and transects, we performed a type-II Wald Chi-squared test using the R package 'car' (Fox et al., 2012). Habitat diversity was characterized by the Shannon index and calculated using the 'vegan' package in $\mathrm{R}$ (Oksanen et al., 2015). Pearson's product-moment correlation was calculated for testing correlations between arable land cover and habitat diversity, as well as forest cover.

Linear mixed-effects models and model averaging methods were applied to test for significant effects of landscape complexity, crop-use type, transect position and their interactions on carabid functional diversity (CWM, FDvar). Species richness and activity density of carabids did not differ significantly between study years, therefore 'year' was used as an additional random factor. We included the factors 'year', 'farmer', 'site' and 'crop type' as nested random effects, as well as 'landscape complexity', 'crop-use type' and 'year' as fixed effects in the model according to the R syntax:

"lmer(y (Landscape Complexity + Crop-use type + Transect) ${ }^{3}+$ $(1 \mid$ Year/Site/Farmer $)+(1 \mid$ Year/Site/Crop type)".

We generated a set of all possible linear combinations of predictor variables for the above model, using the function 'dredge' of the 'MuMIn' package in R (Barton, 2017), which ranks candidate models according to Akaike's Information Criteria, corrected for small sample sizes (AICc). The models with $<2 \Delta$ AICc of the best model (i.e. the model with the lowest AICc) were selected for model averaging using the function 'model.avg' of the 'MuMIn' package. If only one model was left after model selection, we calculated a linear mixed-model with just one explanatory factor (the one from the remaining model) without model selection or averaging.

\section{Results}

In total, we collected 55,165 carabid individuals of 95 species (listed in Table S3). The four most abundant species Pterostichus melanarius (39.1\%), Poecilus cupreus (20.1\%), Harphalus rufipes (11.3\%), and Anchomenus dorsalis (9.8\%) accounted for $80.2 \%$ of the samples. We collected 8894 carabids representing 62 species from conventional winter wheat fields, 13,327 carabids from 72 species from conventional flowering fields, 17,563 carabids from 76 species from organic winter spelt fields and 15,381 carabids from 67 species from organic lentil-mixed-crop fields.

Crop-use type had high importance on feeding type but not body size or flight ability of the carabid assemblages (Table 2 and Fig. 1). Conventional flowering- and organic winter spelt fields, but not spring sown organic lentil mixed-crop fields, had a higher proportion of plant-feeding (omnivorous and herbivorous) carabids than that found in winter wheat fields. Feeding type distribution was not considerably different in organically managed winter spelt compared to lentil-mixed-crop fields, but more plant-feeding carabids were found in flowering fields compared to lentil mixed-crops. Landscape complexity did not affect any trait characteristic or its variance (FDvar) (Table 2).

Transect position had strong effects on all traits studied (Table 2). Compared with those in field centers, carabid assemblages at the field edges were on average smaller, had more plant-feeding carabids and showed increased flight ability. These mean differences were independent of landscape complexity or crop-use type. The variance of body size and feeding type distribution (FDvar) was higher within carabid assemblages at the field edges than at field centres (Table 2, Fig. 
Table 2

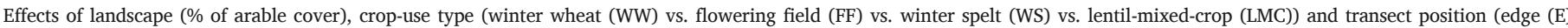

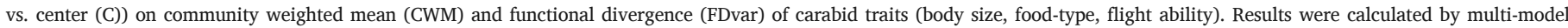

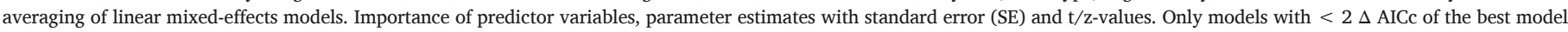
are shown. Bold values indicate significant effect at $P=0.05$.

\begin{tabular}{|c|c|c|c|c|c|}
\hline Response $^{\mathrm{a}}$ & Explanatory & Relative importance[\%] & Multi-model estimate ${ }^{\mathrm{b}}$ & $\pm \mathrm{SE}$ & $\mathrm{t} / \mathrm{z}$ - value \\
\hline CWM size $(0.19 / 0.82 ; 1)$ & Transect (E/C) & 99 & -0.033 & 0.007 & -4.91 \\
\hline \multirow[t]{7}{*}{ CWM feeding type $(0.29 / 0.76 ; 2)$} & Crop-use type (FF/WW) & 100 & -0.187 & 0.031 & 6.022 \\
\hline & Crop-use type (WS/WW) & 100 & -0.120 & 0.031 & 3.823 \\
\hline & Crop-use type (LMC/WW) & 100 & -0.070 & 0.035 & 1.946 \\
\hline & Crop-use type (WS/FF) & 100 & 0.068 & 0.035 & 1.881 \\
\hline & Crop-use type (LMC/FF) & 100 & 0.117 & 0.031 & 3.750 \\
\hline & Crop-use type (WS/LMC) & 100 & -0.050 & 0.031 & 1.603 \\
\hline & Transect (E/C) & 29 & -0.047 & 0.017 & 2.696 \\
\hline CWM flight ability $(0.18 / 0.77 ; 1)$ & Transect (E/C) & 100 & 0.716 & 0.014 & 5.073 \\
\hline FDvar size $(0.29 / 0.59 ; 1)$ & Transect (E/C) & 3 & 0.010 & 0.005 & 2.164 \\
\hline FDvar feeding type $(0.18 / 0.77 ; 1)$ & Transect (E/C) & 27 & 0.030 & 0.010 & 2.819 \\
\hline FDvar flight ability $(0.04 / 0.55 ; 1)$ & Landscape & 3 & 0.019 & 0.035 & 0.595 \\
\hline
\end{tabular}

a All models were fitted with normal distribution (marginal/conditional $\mathrm{R}^{2}$ value of full model; number of candidate models, $\Delta$ AIC $<2$ ).

b Negative estimates indicate lower number e.g. lower CWM size in edge vs. center.

S3a,b). No such difference was found in flight ability (Fig. S3c). The edge effects on feeding type, flight ability and variance in feeding type were most pronounced in winter wheat fields, showing a stronger increase in carnivorous species (Fig. 1a), and a stronger decrease in variance of feeding types (Fig. S3a) as well as in flight ability (Fig. 1c) than elsewhere, although interactions between transect position and crop-use type were not included in the averaged models.

\section{Discussion}

Our study revealed that conventional flowering fields and organic winter spelt, but not spring sown organic lentil mixed-crops, altered the distribution of feeding traits of carabid assemblages, by increasing the proportion of plant-feeding carabids over that found in conventional winter wheat fields. Furthermore, trait characteristics and their divergence were mostly influenced by a distinct difference between field edges and centres, with smaller, less carnivorous and more flight-enabled assemblages at the field edges. The complexity of the surrounding landscape did not influence the functional diversity of carabids within crop fields. These results underline the importance of local farming practices and edge habitats to maintaining the functional diversity of carabid assemblages in arable fields.

\subsection{Effects of crop-use type}

Although both biodiversity specific (flowering fields) and holistic (organic farming) agri-environmental measures led to considerably higher wild plant cover and species richness than did conventionally farmed winter wheat (Table S3), only flowering fields and organic winter spelt increased the proportion of plant feeding carabids within the ground beetle assemblages. The effectiveness of flowering fields in promoting plant-feeding carabids might be associated with the highest total plant species richness, mainly because they were sown with a diverse seed mixture of $15 / 18$ forb species (Table S1), whereas other crop-use types were sown with just one (wheat or spelt) or two (lentil-mixed-crop) plant species. In addition, the species of forb used in the flowering seed mixture varied strongly in origin (many non-native species from different areas) and traits (e.g. size, growth rate, taxonomic distinctness). The overall vegetation structure in flowering fields was thus probably more heterogeneous than elsewhere. Vegetation heterogeneity as well as higher plant species richness can promote plant feeding carabids, as they prefer diverse food resources (Harvey et al., 2008; Woodcock et al., 2009; Rouabah et al., 2015).

Higher wild plant cover and species richness may also explain the positive effects of organic winter spelt crops compared to conventional winter wheat. Winter spelt crops had lower wild plant cover and species richness than lentil mixed-crops (Table S3), but only the former had higher proportion of plant-feeding carabids compared to conventional farming systems (conventional winter wheat). This may be explained by the different sowing time of the two crop-use types. Winter spelt were autumn sown, whereas lentil mixed-crops were spring sown (Table 1). Hence, ripened wild plant seeds, which are an important food resource for plant-feeding carabids (Kulkarni et al., 2015), were present earlier and for a longer period in winter spelt compared to lentil mixed-crops. The majority of plant-feeding species in our study (e.g. Amara, Pterostichus, Poecilus, Harpalus) are primarily spermophagous (Kulkarni et al., 2015), which might explain our findings. Herbivorous carabids are more sensitive to agricultural management than carnivores (Purtauf et al., 2005b; Woodcock et al., 2009), because the latter can still find abundant prey even in intensively farmed fields as they are able to feed on soil-living prey (Haddad et al., 2000). In contrast, herbivores are more dependent on the above-ground resources, such as a diversity of weeds, leading to constrained food resources under intensive farming. Our study confirmed these findings, revealing the lowest proportion of herbivorous carabids in the most intensively farmed crop-use type (winter wheat), which had by far the lowest wild plant cover and species richness. The positive effects of flowering fields for promoting plant-feeding carabids are confirmed by recent studies (Mader et al., 2017; Baulechner et al., 2019). Other studies confirm the positive effects of organic compared to conventional winter cereals on carabid functional diversity as well as on the activity density and richness of plant-feeding carabids (Batáry et al., 2012; Gallé et al., 2018a). Nonetheless, direct comparisons between flowering fields and organic crops in relation to conventional crops are currently missing. Our results point to similar effects between conventional flowering fields and organic winter cereals, but through different mechanisms. Spring sown flowering fields most likely increased proportion of plant-feeding carabids due to higher vegetation heterogeneity, whereas the earlier sowing time of winter compared to spring crops might be the determining factor in organic farming. Effects of flowering fields may appear quickly (Boetzl et al., 2018), are easier to implement than conversion from conventional to organic farming, and are often preferred by farmers as they allow greater flexibility and a higher level of weed control due to regular plowing. On the other hand, farmers of non-productive measures such as flowering fields cannot gain crop yield, therefore the subsidy costs under the AES are much higher compared to productive measures such as organic farming (in our study area more than three times higher, Table 1). As both showed positive effects for plant-feeding carabids, case specific balancing between costs and implementability of different agri-environmental measures 


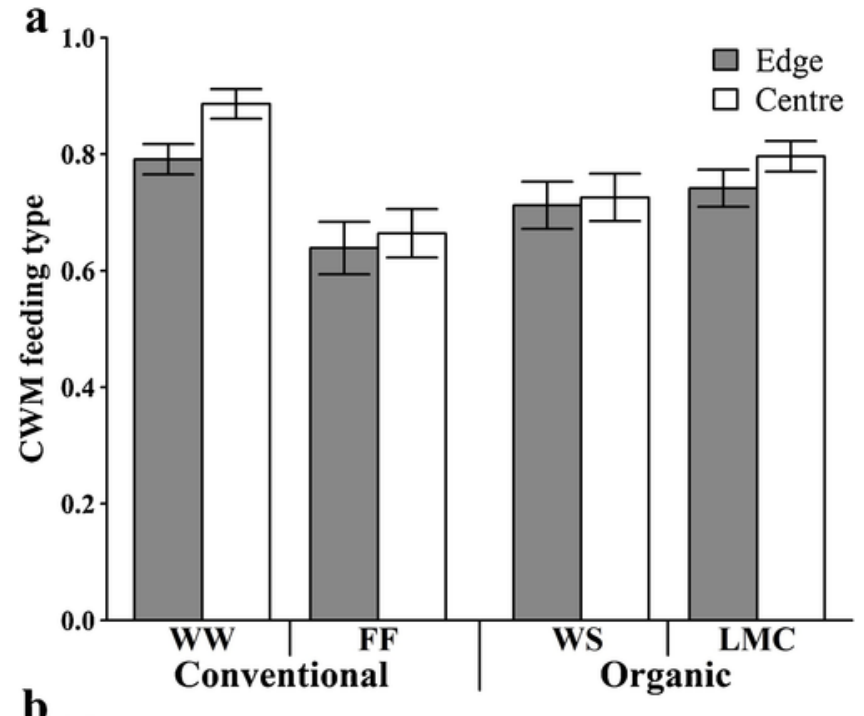

b

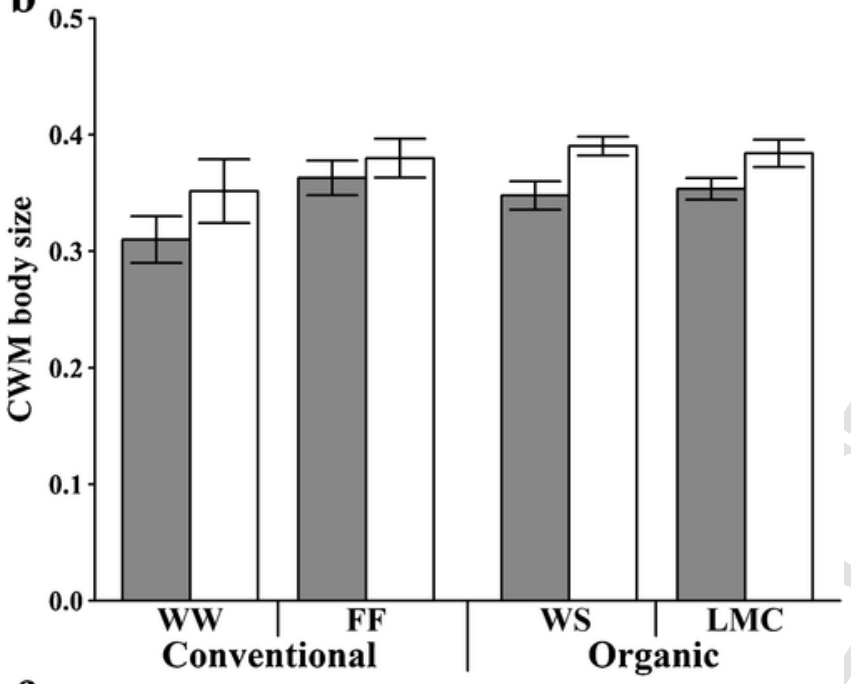

c

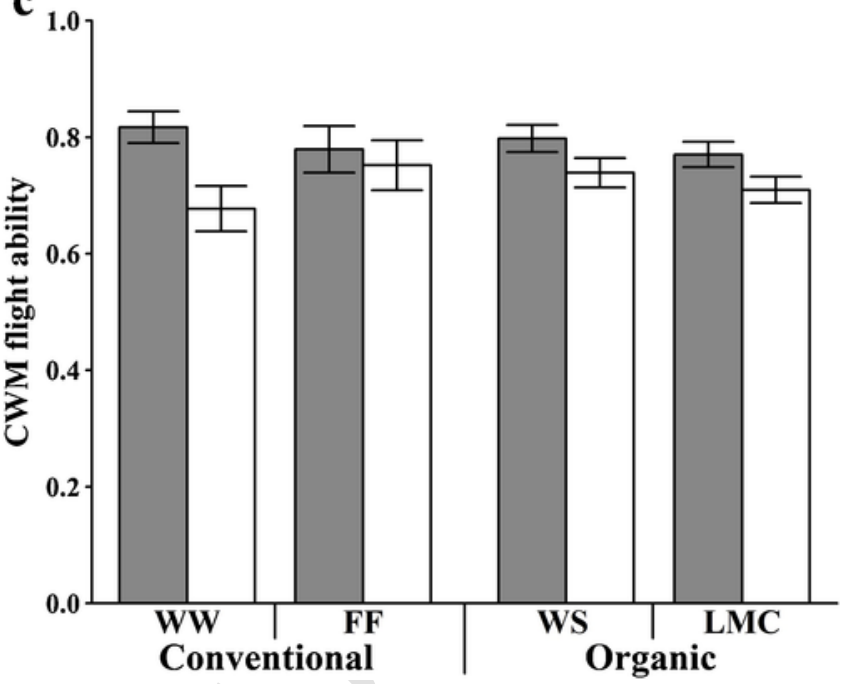

Fig. 1. Effect of crop-use type (winter wheat (WW), flowering field (FF), winter spelt (WD), lentil-mixed-crop (LMC)) and transect position (edge, center) on community weighted mean (CWM) of feeding type (a), body size (b) and flight ability (c). Bars are means \pm SE. may be most suitable in order to increase herbivorous carabid numbers in arable fields.

\subsection{Edge and landscape effects}

Trait characteristics varied strongly between the edge and the center of arable fields, consistent with other studies (Birkhofer et al., 2014; Molina et al., 2014; Rouabah et al., 2015). This was most likely caused by spillover effects between the bordering grassy field margin and the crop field. Grassy field margins are permanent grassland strips that provide season-long food resources and shelter, as they remain relatively undisturbed by agricultural activities. They are important habitats for carabids, which often (but not always, Mansion-Vaquié et al., 2017) disperse into arable fields with a distance-decay effect (Boetzl et al., 2018; Gallé et al., 2018a, b). Compared to crop fields, grassy margins have higher vegetation density, more complex structure, a more temperate microclimate and lower soil disturbance (Schirmel et al., 2016). This in turn can affect carabid assemblages (Rouabah et al., 2015; Labruyere et al., 2016b). The proximity of undisturbed grassy field margins, which benefits herbivorous carabids (Birkhofer et al., 2014), as well as higher plant species richness at the field edges, explains the higher share of plant feeding carabids as well as higher feeding trait diversity at field edges than in the centers.

Higher vegetation heterogeneity and density at the field edge may also have caused distinct differences in carabid body size distributions. The activity density of large carabids positively correlates with homogenous vegetation and low vegetation density, whereas small carabids prefer high plant functional diversity and heterogeneous vegetation (Rouabah et al., 2015). In addition, larger carabids are more mobile than small ones (Homburg et al., 2013), and can therefore disperse further into the crop fields from bordering habitats (Boetzl et al., 2018). These findings can explain our observations of smaller carabids with more diverse size distribution at field edges than centers.

We also found the flight ability of the carabid assemblage higher at the edges than centers, which may be influenced by an interaction of traits. In general, brachypterous carabids in Europe are medium to large carnivores, whereas macropterous species are often small (Den Boer, 1970; Ribera et al., 2001). As we found larger and more carnivorous species, that are often wingless or wing-dimorphic (such as the most abundant species Pterostichus melanarius or the Carabus spp.), in the field centers, the observed differences in flight ability could be explained by an interaction with other traits. As we studied single ecological traits, we were unable to assess possible interactions between traits, although this would be a promising research direction for future studies.

The most pronounced edge effect for feeding type distribution was found in the most intensively farmed crop-use type - winter wheat. Within the field center, the high crop density paired with extreme shortage of other plants reduced the available plant resources, thereby creating suboptimal conditions for herbivorous species. The presence of pest species able to cope with intensive agricultural management, such as aphids or soil-living species, may still provide suitable food resources for carnivorous carabids (Collins et al., 2002; Rouabah et al., 2015). Our results suggest that such habitat conditions may remain sufficient for larger, mobile, carnivorous carabids, but not for species belonging to other functional groups, that can disperse to a lesser extent from the field edges into the centres.

Finally, local effects (crop-use type, transect position) had stronger effects on carabid trait distribution than landscape effects, consistent with other studies analysing species richness and activity density (Tuck et al., 2014; Caro et al., 2016; but see Concepción et al., 2012; Purtauf et al., 2005a). Several studies revealed effects of the surrounding landscape on carnivorous and seed eating carabids (Labruyere et al., 2016a) or body sizes (Gallé et al., 2018b), but others failed to detect 
significant landscape effects on carabid traits (Mader et al., 2017). Within our study region, the biosphere reserve Swabian Alb, soils are poor and stony, therefore land use may be less intensive compared to regions with rich soils. The differences in landscape complexity within our study area were possibly too limited to affect carabid traits more strongly (Caro et al., 2016).

\section{Conclusion}

This study highlights the importance of edge habitats, i.e., grassy field margins, for promoting the functional diversity of carabids in crop fields. Furthermore, we showed that conventional flowering fields and organic winter cereals are equally effective for enhancing the amount of plant-feeding carabids, which may increase essential ecosystem services in arable fields, such as weed seed control. Because non-productive flowering fields are easier to implement, but require higher amount of subsidy payments compared to organic farming, a strict decision between biodiversity specific non-productive measures and productive measures may be of little benefit for the successful implementation of more effective AES for biodiversity conservation. Instead, future AES policy should aim at a diversity of different measures, targeting the enhancement of edge habitats as well as productive and non-productive measures with proven biodiversity benefits, such as flowering fields and organic winter cereals.

\section{Uncited reference}

Fischer et al. (2011).

\section{Acknowledgements}

We thank the farmers for their participation; Nils Engelmann, Caroline Fischer, Miriam Harper, Moritz Mayer and Nina Stork for supporting the plant survey, and Theresa Faessler, Frederik Schuettler and Tobias Weiß for the sampling and identification of carabids. We also thank Emmiline N. Topp for linguistic corrections of the manuscript. Data collection in 2017 was funded by the Stiftung Naturschutzfonds Baden Württemberg (73-8831.21/54691-1703GL). PB was supported by the Economic Development and Innovation Operational Programme of Hungary (GINOP-2.3.2-15-2016-00019).

\section{Appendix A. Supplementary data}

Supplementary material related to this article can be found, in the online version, at doi:https://doi.org/10.1016/j.agee.2019.106579.

\section{References}

Barton, K., 2017. MuMIn: Multi-Model Inference. R package version 1.40.0. In: https:// CRAN.R-project.org $/$ package $=$ MuMIn.

Batáry, P., Holzschuh, A., Orci, K.M., Samu, F., Tscharntke, T., 2012. Responses of plant, insect and spider biodiversity to local and landscape scale management intensity in cereal crops and grasslands. Agric. Ecosyst. Environ. 146, 130-136.

Batáry, P., Dicks, L.V., Kleijn, D., Sutherland, W.J., 2015. The role of agri-environment schemes in conservation and environmental management. Conserv. Biol. 29, 1006-1016.

Bates, D., Maechler, M., Bolker, B., Walker, S., 2015. Fitting linear mixed-effects models using lme4. J. Stat. Softw. 67, 1-48.

Baulechner, D., Diekötter, T., Wolters, V., Jauker, F., 2019. Converting arable land into flowering fields change functional and phylogenetic community structure in ground beetles. Biol. Conserv. 231, 51-58.

de Bello, F., Lavorel, S., Díaz, S., Harrington, R., Cornelissen, J.H.C., Bardgett, R.D., Berg, M.P., Cipriotti, P., Feld, C.K., Hering, D., Silva, P.Mda, Potts, S.G., Sandin, L., Sousa, J.P., Storkey, J., Wardle, D.A., Harrison, P.A., 2010. Towards an assessment of multiple ecosystem processes and services via functional traits. Biodivers. Conserv. 19, 2873-2893.

Birkhofer, K., Wolters, V., Diekötter, T., 2014. Grassy margins along organically managed cereal fields foster trait diversity and taxonomic distinctness of arthropod communities. Insect Conserv. Divers. 7, 274-287.

Boetzl, F.A., Krimmer, E., Krauss, J., Steffan-Dewenter, I., 2018. Agri-environmental schemes promote ground-dwelling predators in adjacent oilseed rape fields: diversity, species traits and distance-decay functions. J. Appl. Ecol. https://doi.org/10.1111/1365 2664.13162.

Bruggen, A.H van, Gamliel, A., Finckh, M.R., 2016. Plant disease management in organic farming systems. Pest Manag. Sci. 72, 30-44.

Caprio, E., Nervo, B., Isaia, M., Allegro, G., Rolando, A., 2015. Organic versus conventional systems in viticulture: comparative effects on spiders and carabids in vineyards and adjacent forests. Agric. Syst. 136, 61-69.

Caro, G., Marrec, R., Gauffre, B., Roncoroni, M., Augiron, S., Bretagnolle, V., 2016. Multi-scale effects of agri-environment schemes on carabid beetles in intensive farmland. Agric. Ecosyst. Environ. 229, 48-56.

Collins, K.L., Boatman, N.D., Wilcox, A., Holland, J.M., Chaney, K., 2002. Influence of beetle banks on cereal aphid predation in winter wheat. Agric. Ecosyst. Environ. 93, 337-350.

Concepción, E.D., Díaz, M., Kleijn, D., Báldi, A., Batáry, P., Clough, Y., Gabriel, D., Herzog, F., Holzschuh, A., Knop, E., Marshall, E.J.P., Tscharntke, T., Verhulst, J., 2012. Interactive effects of landscape context constrain the effectiveness of local agri-environmental management. J. Appl. Ecol. 49, 695-705.

Den Boer, P.J., 1970. On the significance of dispersal power for populations of carabid-beetles (Coleoptera, Carabidae). Oecologia 4, 1-28.

Egorov, E., Gossner, M.M., Meyer, S.T., Weisser, W.W., Brändle, M., 2017. Does plant phylogenetic diversity increase invertebrate herbivory in managed grasslands?. Basic Appl. Ecol. 20, 40-50.

Fischer, C., Thies, C., Tscharntke, T., 2011. Mixed effects of landscape complexity and farming practice on weed seed removal. Perspect. Plant Ecol. Evol. Syst. 13, 297-303. https://doi.org/10.1016/j.ppees.2011.08.001.

Flohre, A., Fischer, C., Aavik, T., Bengtsson, J., Berendse, F., Bommarco, R., Ceryngier, P., Clement, L.W., Dennis, C., Eggers, S., Emmerson, M., Geiger, F., Guerrero, I., Hawro, V., Inchausti, P., Liira, J., Morales, M.B., Onate, J.J., Pärt, T., Weisser, W.W., Winquist, C., Thies, C., Tscharntke, T., 2011. Agricultural intensification and biodiversity partitioning in European landscapes comparing plants, carabids, and birds. Ecol. Appl. 21, $1772-1781$.

Fritsch, F., 2012. Nährstoffgehalte in Düngemitteln und im Erntegut: für die Düngeplanung; für Nährstoffvergleiche. Staatliche Pflanzenberatung Rheinhald-Pfalz, Germany.

Fox, J., Weisberg, S., Bates, D., Fox, M., 2012. Package "car". R Foundation for Statistical ComputingVienna.

Gallé, R., Császár, P., Makra, T., Gallé-Szpisjak, N., Ladányi, Z., Torma, A., Ingle, K., Szilassi, P., 2018. Small-scale agricultural landscapes promote spider and ground beetle densities by offering suitable overwintering sites. Landsc. Ecol. 33, 1435-1446.

Gallé, R., Happe, A.-K., Bosem Baillod, A., Tscharntke, T., Batáry, P., 2018. Landscape configuration, organic management and within-field position drive functional diversity of spiders and carabids. J. Appl. Ecol. 56, 63-72.

Gruber, S., Wahl, E., Zikeli, S., Claupein, W., 2012. Perspektiven und Grenzen der Unkrautregulierung bei Linsen (Lens culinaris) im Ökologischen Landbau -ein Review. Perspectives and limitations of weed control in organic lentils (Lens culinaris): a review. Journal für Kulturpflanzen 64, 365-377.

Haaland, C., Naisbit, R.E., Bersier, L.-F., 2011. Sown wildflower strips for insect conservation: a review. Insect Conserv. Divers. 4, 60-80.

Haddad, N.M., Haarstad, J., Tilman, D., 2000. The effects of long-term nitrogen loading on grassland insect communities. Oecologia 124, 73-84.

Harvey, J.A., van der Putten, W.H., Turin, H., Wagenaar, R., Bezemer, T.M., 2008. Effects of changes in plant species richness and community traits on carabid assemblages and feeding guilds. Agric. Ecosyst. Environ. 127, 100-106.

Henle, K., Alard, D., Clitherow, J., Cobb, P., Firbank, L., Kull, T., McCracken, D., Moritz, R.F.A., Niemelä, J., Rebane, M., Wascher, D., Watt, A., Young, J., 2008. Identifying and managing the conflicts between agriculture and biodiversity conservation in Europe-A review. Agric. Ecosyst. Environ. 124, 60-71.

Homburg, K., Homburg, N., Schäfer, F., Schuldt, A., Assmann, T., 2014. Carabids.org - a dynamic online database of ground beetle species traits (Coleoptera, Carabidae). Insect Conserv. Divers. 7, 195-205.

Homburg, K., Schuldt, A., Drees, C., Assmann, T., 2013. Broad-scale geographic patterns in body size and hind wing development of western Palaearctic carabid beetles (Coleoptera: Carabidae). Ecography 36, 166-177.

Hurka, K., 1996. Carabidae of the Czech and Slovak Republics. Ing. Vit Kabourek, Zlin, Czech Republic.

IFOAM, 2005. Principles of Organic Agriculture. 4 p. available online at: IFOAM International Federation of Organic Agriculture Movements, Bonn, http://www.ifoam.org/.

IUSS Working Group WRB, 2015. World Reference Base for Soil Resources 2014, Update 2015, International Soil Classification System for Naming Soils and Creating Legends for Soil Maps. World Soil Resources Reports, 106. UN-FAO, Roma.

Kleijn, D., Rundlöf, M., Scheper, J., Smith, H.G., Tscharntke, T., 2011. Does conservation on farmland contribute to halting the biodiversity decline?. Trends Ecol. Evol. 26, 474-481.

Kleijn, D., Sutherland, W.J., 2003. How effective are European agri-environment schemes in conserving and promoting biodiversity?. J. Appl. Ecol. 40, 947-969.

Kulkarni, S.S., Dosdall, M.S., Willenborg, J.C., 2015. The role of ground beetles (coleoptera: carabidae) in weed seed consumption: a review. Weed Sci. 63, 355-376.

Labruyere, S., Bohan, D.A., Biju-Duval, L., Ricci, B., Petit, S., 2016. Local, neighbor and landscape effects on the abundance of weed seed-eating carabids in arable fields: a nationwide analysis. Basic Appl. Ecol. 17, 230-239.

Labruyere, S., Ricci, B., Lubac, A., Petit, S., 2016. Crop type, crop management and grass margins affect the abundance and the nutritional state of seed-eating carabid species in arable landscapes. Agric. Ecosyst. Environ. 231, 183-192.

Laliberté, E., Legendre, P., Shipley, B., 2014. Measuring Functional Diversity (FD) From Multiple Traits, and Other Tools for Functional Ecology. R Foundation for Statistical Computing, Vienna.

Larochelle, A., 1990. The Food of Carabid Beetles:(coleoptera: Carabidae, Including Cicindelinae). Association des entomologistes amateurs du Québec, Fabreries Supplement $5,1-132$. 
Lavorel, S., Grigulis, K., McIntyre, S., Williams, N.S.G., Garden, D., Dorrough, J., Berman, S., Quétier, F., Thébault, A., Bonis, A., 2008. Assessing functional diversity in the field - methodology matters!. Funct. Ecol. 22, 134-147.

Leps, J., De Bello, F., Lavorel, S., Berman, S., 2006. Quantifying and interpreting functional diversity of natural communities: practical considerations matter. Preslia 78 , 481-501.

Lövei, G.L., Sunderland, K.D., 1996. Ecology and Behavior of Ground Beetles (Coleoptera: Carabidae). Annu. Rev. Entomol. 41, 231-256.

Mader, V., Diehl, E., Fiedler, D., Thorn, S., Wolters, V., Birkhofer, K., 2017. Trade-offs in arthropod conservation between productive and non-productive agri-environmental schemes along a landscape complexity gradient. Insect Conserv. Divers. 10, 236-247.

Mansion-Vaquié, A., Ferrante, M., Cook, S.M., Pell, J.K., Lövei, G.L., 2017. Manipulating field margins to increase predation intensity in fields of winter wheat (Triticum aestivum). J. Appl. Entomol. 141, 600-611. https://doi.org/10.1111/jen.12385.

Ministerium für Ländlichen Raum und Verbraucherschutz (MLR), 2016. Verwaltungsvorschrift des Ministeriums für Ländlichen Raum und Verbraucherschutz zum Förderprogramm für Agrarumwelt, Klimaschutz und Tierwohl. Verwaltungsvorschrift vom 27.01.2016 (Az.: 25-8872.53).

Molina, G.A.R., Poggio, S.L., Ghersa, C.M., 2014. Epigeal arthropod communities in intensively farmed landscapes: effects of land use mosaics, neighbourhood heterogeneity, and field position. Agric. Ecosyst. Environ. 192, 135-143.

Oksanen, J., Blanchet, F.G., Kindt, R., Legendre, P., Minchin, P.R., O'Hara, R.B., Simpson, G.L., Solymos, P., Stevens, M.H.H., Wagner, H., 2015. Vegan: Community Ecology Package, Version 2.3-0. URL: https://cran.r-project.org/web/packages/vegan.

Pla, L., Casanoves, F., Di-Rienzo, J., 2012. Quantifying Functional Biodiversity. Series: Springer Briefs in Environmental Science. Springer Editorial, Berlin, https://doi.org/ 10.1007/978-94-007-2648-2.

Purtauf, T., Dauber, J., Wolters, V., 2005. The response of carabids to landscape simplification differs between trophic groups. Oecologia 142, 458-464.

Purtauf, T., Roschewitz, I., Dauber, J., Thies, C., Tscharntke, T., Wolters, V., 2005. Landscape context of organic and conventional farms: influences on carabid beetle diversity. Agric. Ecosyst. Environ. 108, 165-174.

R Development Core Team, 2017. R: A Language and Environment for Statistical Computing. R Version 3.4.2. R Foundation for Statistical Computing, Vienna.

Ribera, I., Dolédec, S., Downie, I.S., Foster, G.N., 2001. Effect of land disturbance and stress on species traits of ground beetle assemblages. Ecology 82, 1112-1129.

Ricotta, C., Moretti, M., 2011. CWM and Rao's quadratic diversity: a unified framework for functional ecology. Oecologia 167, 181-188.
Rouabah, A., Villerd, J., Amiaud, B., Plantureux, S., Lasserre-Joulin, F., 2015. Response of carabid beetles diversity and size distribution to the vegetation structure within differently managed field margins. Agric. Ecosyst. Environ. 200, 21-32.

Rusch, A., Bommarco, R., Chiverton, P., Öberg, S., Wallin, H., Wiktelius, S., Ekbom, B., 2013. Response of ground beetle (Coleoptera, Carabidae) communities to changes in agricultural policies in Sweden over two decades. Agric. Ecosyst. Environ. 176, 63-69.

Schirmel, J., Thiele, J., Entling, M.H., Buchholz, S., 2016. Trait composition and functional diversity of spiders and carabids in linear landscape elements. Agric. Ecosyst. Environ. 235, 318-328.

Schlager, P., Krismann, A., Wiedmann, K., Hiltscher, H., Hochschild, V., Schmieder, K., 2013. Multisensoral, object- and GIS-based classification of grassland habitats in the Bio sphere Reserve Schwäbische Alb. Photogrammetrie - Fernerkundung - Geoinformation 2013 (3), 163-172.

The Council of the European Union, 2005. Council Regulation (EC) No 1698/2005 of 20 September 2005 on Support for Rural Development by the European Agricultural Fund for Rural Development (EAFRD).

Tuck, S.L., Winqvist, C., Mota, F., Ahnström, J., Turnbull, L.A., Bengtsson, J., 2014. Land-use intensity and the effects of organic farming on biodiversity: a hierarchical meta-analysis. J. Appl. Ecol. 51, 746-755.

Wang, L., Gruber, S., Claupein, W., 2012. Optimizing lentil-based mixed cropping with different companion crops and plant densities in terms of crop yield and weed control. Org. Agric. 2, 79-87.

Westerink, J., Jongeneel, R., Polman, N., Prager, K., Franks, J., Dupraz, P., Mettepenningen, E., 2017. Collaborative governance arrangements to deliver spatially coordinated agri-environmental management. Land Use Policy 69, 176-192.

Woodcock, B.A., Harrower, C., Redhead, J., Edwards, M., Vanbergen, A.J., Heard, M.S. Roy, D.B., Pywell, R.F., 2014. National patterns of functional diversity and redundancy in predatory ground beetles and bees associated with key UK arable crops. J. Appl. Ecol. 51, 142-151.

Woodcock, B.A., Potts, S.G., Tscheulin, T., Pilgrim, E., Ramsey, A.J., Harrison-Cripps, J., Brown, V.K., Tallowin, J.R., 2009. Responses of invertebrate trophic level, feeding guild and body size to the management of improved grassland field margins. J. Appl. Ecol. 46, 920-929.

Woodcock, B.A., Redhead, J., Vanbergen, A.J., Hulmes, L., Hulmes, S., Peyton, J., Nowakowski, M., Pywell, R.F., Heard, M.S., 2010. Impact of habitat type and landscape structure on biomass, species richness and functional diversity of ground beetles. Agric. Ecosyst. Environ. 139, 181-186. 